\title{
Surfaces
}

\section{Murray Krieger's "Everyday Language, Literary Language, and the Problem of Translation" \\ Roundtable Discussion}

\author{
Hazard Adams, Ernst Behler, Hendrik Birus, Jacques Derrida, Wolfgang Iser, \\ Murray Krieger, Hillis Miller, Ludwig Pfeiffer, Bill Readings, Ching-hsien Wang \\ et Pauline $\mathrm{Yu}$
}

Volume 6, 1996

DISCUSSIONS DU PREMIER CONGRÈS INTERNATIONAL SUR LE DISCOURS HUMANISTE

DISCUSSIONS FROM THE FIRST INTERNATIONAL CONFERENCE ON HUMANISTIC DISCOURSE

URI : https://id.erudit.org/iderudit/1064838ar

DOI : https://doi.org/10.7202/1064838ar

Aller au sommaire du numéro

Éditeur(s)

Les Presses de l’Université de Montréal

ISSN

1188-2492 (imprimé)

1200-5320 (numérique)

Découvrir la revue

Citer ce document

Adams, H., Behler, E., Birus, H., Derrida, J., Iser, W., Krieger, M., Miller, H., Pfeiffer, L., Readings, B., Wang, C.-h. \& Yu, P. (1996). Murray Krieger's

"Everyday Language, Literary Language, and the Problem of Translation": Roundtable Discussion. Surfaces, 6. https://doi.org/10.7202/1064838ar
Résumé de l'article

Ces discussions autour du texte de Murray Krieger, « Everyday Language, Literary Language, and the Problem of Translation », ont eu lieu en avril 1994, dans le cadre du premier Congrès sur le Discours Humaniste. Les

communications de cette première réunion du Congrès ont été publiées dans le volume 4 de Surfaces (1994).
Copyright (C Hazard Adams, Ernst Behler, Hendrik Birus, Jacques Derrida, Wolfgang Iser, Murray Krieger, Hillis Miller, Ludwig Pfeiffer, Bill Readings, Ching-hsien Wang et Pauline $\mathrm{Yu}, 1996$
Ce document est protégé par la loi sur le droit d'auteur. L’utilisation des services d'Érudit (y compris la reproduction) est assujettie à sa politique d'utilisation que vous pouvez consulter en ligne.

https://apropos.erudit.org/fr/usagers/politique-dutilisation/ 


\title{
Murray Krieger's "Everyday Language, Literary Language, and the Problem of Translation" Roundtable Discussion
}

\author{
Hazard Adams \\ Ernst Behler \\ Hendrick Birus \\ Jacques Derrida \\ Wolfgang Iser \\ Murray Krieger \\ Hillis Miller \\ Ludwig Pfeiffer \\ Bill Readings \\ Ching-hsien Wang \\ Pauline $\mathrm{Yu}$
}

Surfaces Vol. VI.101 (v.1.0A - 05/08/1996) - ISSN:

1188-2492

Copyright for texts published in Surfaces remains the property of authors. However, any further publication should be accompanied by an acknowledgement of Surfaces as the place of initial publication.
ABSTRACT
This roundtable discussion of "Everyday Language, Literary Language, and the Problem of Translation", Murray Krieger's contribution to the first International Conference for Humanistic Discourses, was held in April, 1994. The papers of this first meeting of the ICHD have been published in volume 4 of Surfaces (1994). 


\section{RÉSUMÉ}

Ces discussions autour du texte de Murray

Krieger, "Everyday Language, Literary

Language, and the Problem of Translation", ont

eu lieu en avril 1994, dans le cadre du premier

Congrès sur le Discours Humaniste. Les

communications de cette première réunion du

Congrès ont été publiées dans le volume 4 de

Surfaces (1994).

Krieger : As I suggested in one of the questions we distributed, one of the major objectives of our comparative project is to find similarities and differences in the ways that Western and Far Eastern cultures relate the discourses of the arts, and especially literary discourse, to their cultural discourse at large, assuming that there is such a thing as "cultural discourse at large" in any of the cultures. I'm thinking of course of many of the papers we've been reading, which remind us of how split and disrupted the notion of cultural discourse really is, and how unusable it is as a generic term. Still, we use it as a generic term, and as I said, I am concerned as I look forward to the East Asian scholars next year, wondering how the discourse of the arts - literary discourse - relates to the cultural discourse at large there in those cultures in comparison to our own, to our own several cultures here.

So, I wanted - despite the problem of what cultural discourse is and how splintered a term it really should be, of how much nominalism intrudes upon our essentialist habits of language - still, I wanted preliminarily, in my paper, to present just one basic and much too simple practical problem, but a practical problem nonetheless that our enterprise must face, even though putting the problem this way introduces all sorts of perhaps retrograde theoretical assumptions. I still want to worry about what we used to call, and some still do call, "the literary," and I have Hillis's paper especially in mind as questioning whether there are other than ideological grounds for such a term. But I want to worry about this before simply accommodating all texts to culture at large, before reducing our valuing of so-called literary texts to nothing more than ideological prejudice. And I'm proposing this limiting notion of the literary and the concern about the literary versus the rest of 
discourse since these are the kinds of texts - the socalled literary texts - that I want to access in these other cultures that we'll be learning about next year. Those are the texts I want to be able to have access to in those cultures. And in those cultures I want to find out: Does the literary furnish us with a special opening to a culture's vision, so that perhaps it is worth trying to preserve its specialness?

In the paper I recognize that we have trouble enough with the translation of texts, with the translation of literary texts, within the Eurocentric family of languages. What greater difficulty, and is it only a difficulty in degree, we must have in reaching beyond to texts that are clearly in other families of other languages very very very alien to our own historically, culturally? And so in my paper, I did allow this concern to lead to the age-old question, one debated so long in the history of our own tradition, of whether the literary is a unique mode of discourse exhibiting special resistance to translation, or whether it is rather only an exemplary discourse to be used by us to reveal a similar resistance in all discourse. And so I suggested in the paper a rapid history of the oscillations between arguments for a separatist view of the literary - of "poetry" - as one of the arts, and for a levelling of poetry, the literary, the poetic, whatever, as just a part of language and culture considered generically. I'm using the terms "the literary" and "poetry" and so on in the Aristotelian sense of simply any self-conscious fiction. Of course, "fiction" and "selfconscious" introduce a whole series of other problems that I'm bypassing.

In providing this history of the oscillation between the separatist and the generic sense of discourses, I use Diderot and Herder, followed by German Romanticism and its English mouthpiece, Coleridge, to mark the final rise of the poetic, or the literary, to its highest separatist moment as a special kind of discourse that, one way or another, continued to the middle of the twentieth century. In formulating this formalist opposition, there was automatically, as a consequence, as a corollary, a minimalizing, contemptuous view of the non-literary, as if there were such a thing as non-literary, "normal," and so on. One thinks of Mallarmé's newspaper language notion, from Mallarmé's newspaper language to Cleanth Brooks's notion of a simplistic one-to-one reference between signifier and signified, and an increasingly idolatrous view of poetic language in all of its internal complexities, in contrast to that one-to-one simplistic reference. 
Now of course, the latest swing during the past one-third of the century, our time, has been back to deprivileging the literary and the discourse of the arts in general; it ends really by privileging all our uses of discourse, that is, by using the techniques of reading formerly reserved for the literary and applying them generically to cultural discourse high and low, so that everything becomes subject to this kind of intensive reading. Does this move not leave us with a problem of cultural translation that is all the more difficult - I hesitate to say impossible - for all discourse, especially if we splinter each culture into its discursive dis-sensus, of which Hillis has spoken, or rather will speak. In other words, unlike the problem of translation that we used to think of as only concerned with the literary, with the assumption that everything else was translatable back and forth from culture to culture - does not this much more intensive expansion of these problems of reading (that some of the people around this table have done more to alert us to than anyone else perhaps), does it not darken the problem of the possibility of cross-cultural transmission more than ever? I'll close now, momentarily, on this dark note, and hope that the discussion might brighten things up.

Birus : Thank you very much. I think your paper, that has such a balance between systematic and historical arguments, which provides a good occasion to enter these two areas of reflection, reflection on the historical point where we now are and on these systematic implications. And I would like to underline now only three points for the discussion of the first two pages you gave us. The first: You lay stress on - - it's in one of the first lines - "at a time when this moment now of international communication," and so on. And I remembered exactly this argument was basic for Goethe in the moment he elaborated his concept of world literature, because he said that such a world literature as it is inevitable with the ever increasing speed of traffic, will soon come into being. He compared his situation with the sorcerer's apprentice (in his wellknown ballad). He said: With the "advancing world literature streaming towards him as if to engulf him," he related the resulting "universal world literature" rising up, not only in a general way to the "contemporary, highly turbulent epoch" and its "vastly facilitated communications," but also quite concretely to the constantly "spreading activities of trade and commerce," in which he saw that "the human spirit gradually attains the desire to participate in the more or less untrammelled intellectual trade." So you see, as you have shown in other parts of your paper, the situation is 
not as new as we sometimes have the feeling. It is prepared decades and centuries ago.

Krieger : By the way, did Goethe mean by "world literature" really "world literature," or did he not exclude Asia?

Birus : No. He found this concept in reading a Chinese novel. He said to Eckermann, "I see increasingly that poetry is a common property of mankind and that it emerges in all places and at all times from many hundreds of people. Some are a little better at it than others and stay on top a little longer, that is all there is to it... Everyone must realize that the gift of poetry is not so rare a thing, and that nobody has reason to let it go to his head if he produces a good poem." And then he reported of this Chinese novel Yü-chiao-li (Red Jade and Dream Pear), and as Eckermann asked, "Well, that must be very special," Goethe answered: "Not at all. The Chinese have thousands of such novels and had them while our ancestors were still living in the forests." And then, the second point: you say we have been confirming an intimidatingly wide range of cultures, and so on. In East Asia we see the translations of the holy texts of Buddhism from Indian to Tibetan, Chinese, Korean, and Japanese. There we have languages that are not related to each other. But this transfer was possible, and there it was also possible to translate poetical texts, and we should ask what was translated and what was not able to be translated. I think next year, we should deal especially also with these problems of translation. And the last point: Reading translations or only the original texts. Goethe held the strong conviction that one should, as far as possible, "seek out, get to know, and cherish each poet in his own language and within the specific era of his time and customs." Why else would he, for the sake of Hafiz, have begun to learn Persian at the age of sixtyfive? But on the other hand, he wrote in his review of Carlyle's German Romance: "Whatever one may say about the shortcomings of translation, it nonetheless remains one of the most important and most worthy activities in the business of the world. The Koran says: 'God has given each people a prophet in its own tongue.' Every translator is thus a prophet in the midst of his own people." So Goethe asked for a prose translation of each important poetical work. You could answer: well, that is the heresy of paraphrase, and it was before modernism. But remember that Mallarmé made his translation of Edgar Allan Poe's "Nevermore" in prose, and Nabokov made a prose translation of Pushkin's Eugenij Onegin. I think the way you pose the problem in systematic and historical terms can be a good way to come to principal 
questions and to look for answers given generations before.

Krieger : You know, one of the things we could do, or some of us might do, would be to examine precisely the extent to which, in past times, the act of translation has occurred. I mean, we can't read Schopenhauer without knowing how deeply Asian thought was there, or, well, go back to Plotinus. In so many ways, there are translations, but we must look at them in the new ways that some of our papers - and I think of Wolfgang's question as acts of appropriation, where we're simply taking what we need and what we want and what our own perspectives permit us to see, so that we are imposing ourselves into what we claim to be the other. It's Hillis's question of the other that we make our own, but in making it our own it's no longer other, and to that extent, the act of translation is a fraud. And the extent to which that kind of self-deception occurs in cultures is of course so much of our problem. As we look at the history of Western thought, we must worry about the extent to which we say, oh yes, we've used and we've been influenced by this in the orient and that in the orient, but only in order to re-accentuate that which we look to find in it.

Miller : This reminds me of a story about Danny Kaye, the American comedian, which I heard in Israel. He was taken to see the Dead Sea Scrolls. He said, "Oh! I didn't know the Bible had been translated into Hebrew!"

Derrida : The first problem of translation for me is to speak English, not only because my English is poor and because I have to translate myself into English, but also because I'm tired and so it will be a problem for me. I apologize for the awkwardness of my English.

Now I have two or three very poor preliminary questions about translation. Pre-pre-preliminary. First, about what you just said about appropriation or non-appropriation. There have been a number of debates in Germany at the beginning of the nineteenth century about at least a competing, conflicting concept of translation, one being appropriation, the other being translating oneself into the other. These two axioms have conflicted, and there has been a rich debate in Germany on them. Now my questions have to do with the very translation of the concepts of literature and even translation. You see, there are many ways in which we Westerners could try and, let's say, deny or raise the possibility of literature in the Eastern cultures. Two ways: One would be by simply saying, well, they don't have something, such a thing like 
poetry, novel, and so on, have no literature. That's the brutal Eurocentric denial. The other one would be to say exactly the opposite: There is a world literature, and of course they are writing poetry, and so on and so forth. I think the result is the same. That is, in both cases, we don't take into account the strict limits of the European concept of literature with its history, and there are things that we think we recognize as poetry and novels and so on in the Eastern countries, but it's not sure that they belong to this institution we call literature, which has a very complex history in Europe, and a very recent, a very modern one. It is not certain that the enormous treasure of what we call Chinese or Indian poetry belongs to what we call literature. That's something we should not only ask, but elaborate with, ask our Indian, Korean, Chinese, Japanese colleagues ask them first if they think that what they are. They may make the same mistake as us, that is, reduce their own production to poetry or literature in the sense that we do. So what do they do when they translate literature into this or that genre. What happens then? And thus the very concept of literature has its history, a history which is not simply the history of poetry - literature is not poetry, for instance. So what happens here? And the concept of translation - of course there are a number of heterogeneous concepts of translation in Europe already (I mentioned just one of them a moment ago), but what about non-European concepts of translation? What do they do in China, in Japan, when they translate, when they use the word "translation"? How do they translate the word "translation"? What do they do, what do they think they do when they use the word? So these are very poor questions, but preliminary ones. I would say the same with "culture," the concept of culture, of course. To ask these questions (and I think what I am saying goes along with what you say in your paper), to elaborate these questions doesn't run the risk, I think, of, let's say, what you call nominalism. We have to take seriously the name, the nouns, and the fact that sometimes they are not related to the same concepts. Now, just one more point, Murray, about two things you said, not in your paper but in your oral presentation. You say, well, when I use the word "literature," I'm only meaning "selfconscious fiction" in the broadest, in the broader sense.

Krieger : I was using Aristotle. Our tradition.

Derrida : Well, even in the very broad sense, it's difficult to define literature as a self-conscious fiction because there are a number of other self-conscious fictions you wouldn't call literature or, literary. Self-conscious fiction is a very very broad concept. To pay attention to self- 
conscious fictions, to the number of different structures you could define as self-conscious fictions, to pay attention to these in the everyday or in the cultural field, generally speaking, doesn't necessarily amount to deprivileging literature. We can be very attentive and respectful to all the specificity of the "literary," and nevertheless pay rigorous attention to methods which sometimes look like literary theoretical methods without erasing the specificity of literature. Okay? Now, I will be tempted to say that to avoid, to save on the rigor of the literary, wherever it occurs, doesn't consist necessarily in essentializing the literary. I think there is no such thing as literature, literary essence, but when I say such a thing I think I'm still able to define the literary function with its historical and institutional implications, and to have a rigorous respect for the specificity of this literary function without essentializing literature. But in order to do so, we have to take into account the history of this function (that was the institution I mentioned a moment ago). And the history of this function is probably something we have to refer to when we elaborate the question I started with, the translation of the concept of translation, of literature, and so on and so forth.

Krieger : I just want to say one word, and that is that I agree absolutely, and would want very much to emphasize the literary function, as you say, rather than to essentialize literature. It's for that reason that I spoke of a way of reading, suggesting only that what we have learned to do is to read many many many things without the compartmentalization that the essentializing of literature would lead us to. Yet often I think our methods turn out to be methods that we may have, in our own private ways of reading, learned by reading literature.

Readings : I'd like continue on that line, Murray, by saying that what worries me about the history you give, if it is insufficiently historical, in the sense that it is too continuous, is that you presume retroactively that the concept of literature can be applied to Aristotle. I personally don't think so. I'm a bit of an idiot about literature, I mean I think about literature as an idiom, a way of talking, that I've never quite learnt, and I can't read Aristotle and line it up with the things I hear, for example, German Romantics saying about literature. It seems to me that the discontinuity between a poetics and an aesthetics is more historical than that. For example, the sort of opposition you set up between rhetoricity and something like literature - it doesn't seem to me to be operative for Sydney in the Renaissance. I think there's a different way of organizing the way we use language. And I'd like to sort of spin that out to say 
something about the appeal to a "we." Sometimes I worry about the "we" in your paper, because it presumes that there is a tradition that is ours, that is continuous, that stretches from Aristotle to the present. Now I mean I know you don't think that, but...

Krieger : It has an academic validity.

Readings : Yes. But the idea of the history of Western thought is an idea marked essentially or deeply by the figure of translation, by the notion of translatio, by the possibility of the Renaissance thought of translation as the way of understanding what culture is. And I'd say the modern idea of culture comes out of a Renaissance theorizing of translation as a way of identifying symbolic life and giving it a history which would allow for renaissance or renewal. So in that sense, I'd sort of want to back up to what Jacques said about the fact that the very preliminary kinds of questions about the function of translation in constituting the modern idea of culture seemed to me to require attention in a way that will perhaps break up the kind of opposition of blocs of - you know, like the "us" and "them" - oppositions that you refer to in your paper.

Krieger : I think the "us" and "them" are never more clearly marked than in the habit of translation in the past. What we're trying to do here, it seems to me, is to recover a way of translation that doesn't fall victim to what translation through history has shown us. I would argue, by the way, differently about the relation of Aristotle to the notions of rhetoricity versus poeticity in the Renaissance thinkers. We could talk at length about other transcriptions of Longinus's distinction in the eighteenth century, and so on. It seems to me that when I speak historically, I'm speaking not of history, the real history; I'm speaking of the history of literary discourse, or rather of critical discourse as it has been passed, been translated if you will, from period to period. So it's the history of an institution rather than history of the real question, Did Aristotle actually affect this person? Did Aristotle's meanings of poetics mean, or have anything in common with, what happened in the sixteenth century or the seventeenth? The sixteenth and seventeenth centuries which adapted Aristotle, thought so, and that was an act of translation, as you said. But in terms of the history of the institution, it doesn't seem to me inappropriate to put these people together in what I admit is a very very over-simplified summary of what I see as disruptive oscillations. You speak of continuousness; it seems to me that rather than continuity what you do have is disruption, and often 
within a single historical moment with all these things going together. Oscillation's a bad word, suggests a before and an after that first it swings this way, then it swings back, and then it swings up, and then it swings down, whereas actually what you have are notions far more in conflict at a single moment. When you look at Scaliger's attitude toward the relation of rhetoric to poetry in the sixteenth century and look at Mazzoni's attitude or Castelvetro's, these are significantly in conflict with one another.

Readings : But they have a notion of poetry. What I'm less convinced of is the fact that they have a notion of literature. That is to say, I don't think that you could say, poetry as a way of making things with words, a way of making with words, rhetoric as a way of making with words - that seems to me utterly unquestionable. I have no problem at all when you say that. What worries me historically is that I'm not sure that one can apply the word "literature," which I find to be sort of centered in modern German Idealism, to that attitude. I'm just not sure what the stakes are in that translation.

Krieger : Yes, I was using "the literary" and "the poetic" in somewhat interchangeable ways.

Readings : I'm saying, you know, "the literary" emerges with reception.

Derrida : There is a history of the word "literature" which is very resonant with the sixteenth, seventeenth century.

Readings : Of course.

Behler : I would like to ask a question along the lines raised by Jacques Derrida and Bill Readings concerning the privileging of literature, and especially poetry. We know from the rhetorical tradition how poetry became distinguished from other forms of discourse, through certain arrangement of words and technical features, as they are well described in rhetorical handbooks of the Renaissance and earlier periods, by Longinus, and others. But I think that the distinction of poetry and literature became very crucial toward the end of the eighteenth century, not on grounds of words and arrangements of words, but on grounds of metaphysical presuppositions, namely the distinction of symbol and allegory, the merely allegorical type of poetizing, saying it otherwise, and the symbolic type of saying, symballein, reaching beyond the radius of language into Being as such, so to speak. Goethe's notion of symbol comes to 
mind. And at the height of this tradition, we have Heidegger reading Holderlin. It's no longer a language that speaks; it is something much more: language that has ontological access. And I think some of the reasons raised for the untranslatability of poetry derive from this tradition: Goethe, symbolism, Heidegger - which raises poetry to a level far above and beyond language. That is also something, of course, one has to look at very critically in a discussion like ours.

Krieger : Yes, I agree. From my very first essay in 1950, this distinction is something that has been at the center of my concerns. I would want to add one thing, however, beyond what you have said, and that is that within the typological tradition of the Renaissance, within what Auerbach calls the "figural" tradition of the Renaissance and the notion of the figura itself, there is a strenuous way of putting forth - - granted with a theological, a theological and thus ontological ground - a notion of symbol that is an important precursor to what is happening in the late eighteenth and nineteenth century use of these terms. And to that extent, the notion of symbolic reading is hardly invented in the late eighteenth and nineteenth centuries; it's basic to the very habit of the late Medieval/ Renaissance hermeneutic.

Behler : Even Dante's Commedia is a completely allegorical work, but the way he moves into the theological...

Krieger : But when you get to the anagogic phase, all allegory disappears. Everything evaporates into symbol.

Pfeiffer : If we are tempted to emphasize, let's say, the mere appearance of continuity in theory and conceptualization, it appears to us that there is a continuity. But I do also think that it's highly doubtful whether there is in fact a continuity even in theory. It looks like one, but I don't think there is. So if we emphasize in some way discontinuity, what do we place then in the gaps which open up? If it's no longer a continuity of theory or of literary practice with respect to culture, what then is supposed to fill the gaps which are there? Is it then something else than literature or what we use as a historical notion of literature, other media, or whatever?

Krieger : Of course this is what's happened in all of our papers and in Jacques' comments. We all of us are continually using words that we know have no generic content because they explode into so many binaries. We 
use historical notions of continuity knowing that they cover all these gaps and spaces which, in a way, totally delegitimize them. And yet we speak. There is always the great difficulty of trying at every moment to have our discourse encompass everything that we are skipping in the language that we are reduced to. This is the scholar's problem always. The world never behaves the way our language wants it to. And we try to pay attention to that, but we still try, at the same time, to make discourse, and so we're stuck with what we half allow our language to deceive us into believing.

Readings : But on the same sense, the institutions that are going to govern the possibility of translation are inevitably going to weigh, or load, the question of how translation proceeds. That is to say, if we decide that the word "culture" or the word "literature" is the ground upon which we're going to perform an intercultural translation, it's simply pragmatically accepting the existence of nation-states and language families, then the stakes of that word will govern, load, bias, whatever, the possibility of translation, so I mean it does seem to me that that's a very very important question.

Krieger : I wasn't trying to minimize the question. I was simply trying to remind us how delicately we have to straddle the fence between speaking and being aware of what our speech might be forcing us to imperialize.

Iser : The question of translating cultures is a problem insofar as the space between cultures cannot be coped with by any kind of thirdness. Thus whenever translation occurs different ways of coping with that space appear to be necessary such as negotiating, porting over, carrying across, which imply different activities in regard to how we relate to the space between whenever translation takes place.

Birus : I would like to say that Goethe's concept of world literature is beyond the alternative you have posed. World literature is not anything that exists as a house of mankind, but it's something that is emerging in this moment. And the second thing is that his idea of world literature doesn't imply a canon or a hierarchization. Remember that his appreciation for a special Chinese novel didn't mean that it was one of the best, but that it was interesting here and now. Well, in the background there was the Greek canon as an Archimedean point.

Krieger : And he worried that that would be overrun by world literature. 
Derrida : I don't know these texts, but I would say it's a bit worse to say this, because to say... I understand the emerging world literature is something he calls for, performatively tries to produce. But to call this coming production, this production to come, to call it literature, world literature, littérature, even if one doesn't establish new canons by this simple premier fact of calling this literature, using what you call the background of paradigms, is already - well, I wouldn't call this... wouldn't use stereotypes such as Eurocentric or imperialistic - but there's some...

Yu : Universalizing.

Derrida : ... some universalizing according to a model which is the model of literature, of the given literature, and the convention for his performative, so to speak, the convention which guarantees his performative - that is, a call for a literature to come, a world literature to come the convention is the existing literature, European, institutionally existing literature. From that point of view, it's - even if he respects the future and the unforeseeability of the future, he nevertheless tries to rule, to give a pre- - a telos, a telos, which is not a canon. It is not a canon, but some telos.

Krieger : Jacques, how would one go about apprehending the "out there," those pages out there?

Derrida : I would refrain from calling this literature.

Krieger : I understand. No, no, no. Okay, I'm not calling it literature, and it's out there.

Derrida : I have nothing against it really, of course. But out of my respect for literature, I wouldn't call literature everything, everything, every language, written or spoken language to come - out of my respect for it.

Krieger : No, I agree. But I'm asking, now, in our innocence, what do we do with it?

Derrida : With the future, you mean.

Krieger : That piece of paper that's thrust in front of you that has no name and no category, since our mind is full of the categories that we poor people are stuck with. What do we do with it?

Derrida : What do we do with it. We will try to find new names for it, a new name for what is coming. 
Yu : This is the topic of this whole session, of the whole conference. How can we not have a position from which we speak, and which carries with it all sorts of conceptual baggage, and that we then package... put this other into when we encounter it. I mean, I'm not sure if there's any way of getting around it, but the least we can do is recognize what the position does bring with it. My insertion was going to be about five topics back when both of you raised the issue of the importance of recognizing certain historicity in this narrative that you're tracing, that there may be oscillations, but there are also moments at which things really do shift significantly and the whole terms of the argument shift significantly. I think this end of the eighteenth century, beginning of the nineteenth century, when you have this insistence on the untranslatability of poetry that's related to a new spin on the notion of the symbol, and also the charge that's placed on translation as an access into something larger, something cultural, or whatever, is really one of these moments of disruption. If you look at earlier theories of translation, the sixteenth, seventeenth century, there's a lot of disagreement on the techniques of how you're going to do these things, but I don't think there's really the same problematic that's there. I mean there's always the assurance that you can do it. You may disagree on how you're going to do it, but the fundamental impossibility is not there. And so the relationship of translation, theories of translation, to critical theory, to poetic theory, is...

Behler : For the Renaissance, the turn to the Greek past was no great problem, there was no notion of untranslatability of the Greeks. Or look at Toledo, the Middle Ages, the twelfth century, and the translation of Aristotle. Five people sat together. One read the word in Greek, the next said it in Hebrew, and then someone said it in Latin, and this way the text was translated without great ado. The problems we are talking about are problems of Romanticism. They are the inheritance of an over-inflated notion of poetic diction, poetic value, literary value, and a privileging of literature and poetry over other modes of expression.

Krieger : I just wondered for a moment whether that kind of total blockage that Romantic theory would impose, that is, the untranslatability of that thing out there that is other, whether that in some ways is something like the problem that Jacques has brought to us, namely that new series of texts from an alien culture to which we cannot appropriate or impose our terminology, our generic categories - literature, novels, 
poems, whatever - whether their inaccessibility as a something out there that is unaccommodatable is in some ways the same kind of problem, though to a very very different degree.

Miller : I've been brooding since Murray first began, thinking about his paper, about a question which shifts a little bit what we have been talking about. This is the question of why one would want cross-cultural translation at all. One could imagine saying: Let's leave these other cultures alone and defend our own, and teach our own. The context for me is what's going on in the United States in our universities. I want crosscultural translation, but I want to be sure why we want it and what we're up to. I was at a conference in New York the other day, and there was a very good, commonsensical, and powerful speech by Anthony Appiah, who teaches in the African-American program at Harvard. He argued the necessity of teaching in our schools and colleges lots of different cultures. The key word that he used, however, was not the word "appropriation," nor even "understanding," but simply "respect." That was really all he hoped for - respect. You used the word "splintering" for my idea of dissensus. He said, "I admit that doing this, teaching many different cultures in our universities, would be" - his word was "destabilizing." It would be "destabilizing" for the students who come with their own cultures, whatever they are, and are, by the circumstances of the curriculum, only encouraged, in many of our universities now it's very hard to avoid it - to study cultures different from their own, that is to say, to make an effort of cross-cultural translation, presuming that it can occur. The discussion has mentioned the long tradition of Goethe's attitude towards this. I can think of three different reasons one might want cross-cultural translation. They all make me a little uncomfortable. One of them is that, from a Western point of view, these things are simply there to be known. It's our business to know them all, and that involves translating them so that they can be assimilated, and so on. It's not exactly appropriation, because nobody really claims you're doing that. I had a colleague at John Hopkins, a learned Sanskrit scholar, who spent his whole life translating what looked to me like minor Sanskrit texts. Sanskrit literature is an enormous literature, as we know; major poetic texts have long since been translated and are very important. He was translating cooking manuals, and that kind of thing. That was considered at Hopkins to be an entirely worthy thing for that man to do. He ended up with a long line of these, published I guess by the Hopkins Press, and there they sit. If you want to read in 
English a Sanskrit work about how to cook, this scholar did it. That strikes me as a problematic, a very problematic reason for translation. Nevertheless, there's a little bit of that in Goethe, you know. There they are, these novels; I say they're literature; we must translate them into German so everybody can read them.

Krieger : And it's the old Ph.D. justification of making a contribution to knowledge in one's dissertation.

Yu : Now we have a Sanskrit cookbook paradigm.

Wang : That Chinese book Goethe mentioned is not a very important novel at all.

Birus : Exactly. And he knew it.

Miller : A second reason for translation would be the one that Ernst mentioned, which I think has great power in our culture. That is the sense that literature, so-called, with all the problems that Jacques spoke of - - the assumption that the Bhagavad Gita is literature in some way, religious literature, something, or that these Chinese poems are like our poems, that they have a symbolic value, that is to say, a spiritual value - there's something that we can get from them that we can't get from our own literature; therefore we need them. If we can't read Chinese, it's better to read them in the best translation possible. That is to say that they add something irreplaceable to the collection that we have now. A slightly different version of that: I remember reading in translation - everybody knows that Constance Garnett made everything Russian sound the same Turgenev sounded like Tolstoy, Tolstoy sounded like Dostoyevsky - but I read all those things at a certain moment, not exactly because I thought it was going to give me some kind of access to spiritual realities, but something not entirely different from that. I thought there was somewhere I could get to by reading even a bad translation of The Brothers Karamazov that I couldn't get to in any other way. That was certainly my motive for learning European languages.

That's different from the Anthony Appiah reason, my third reason, which is to enhance and protect these minority cultures by learning enough about them so that you respect them without necessarily being able to understand them from the inside. So I see the whole assumption that we're basing our conference on, that is the desirability of cross-cultural translation, as being really problematic. We're all, I think, a little afraid that we sitting around the table here could end up being 
simply the instruments of another kind of appropriation. The question is, how can you avoid that? The context in the United States now is the rapid proliferation of programs which are attractive to students in which, for example, without being a Native American you take courses in Native American literature in translation, taught often by somebody who's not a Native American. Or you take courses in African-American or Chicano literature. Maybe you learn a little bit of Spanish, and so on. And while you're doing that, by the way, you're not spending as much time doing something we all know is a lifetime of work, that is appropriating as best you can the European tradition, or even, let's say, even learning just English literature. You can spend your whole life doing that, and still not really get inside it. I have not read all of the plays of Beaumont and Fletcher, I regret to say. It might be very important for somebody to do that. I was on an evaluating committee for the Program in Literature at Duke - very distinguished program Fred Jameson as director, people like Toril Moi, and so on. In spite of Jameson saying "Always historicize," history has just about vanished from that program. It's all modernism and post-modernism. They do courses in Arabic novel...

Yu : In English? Oh, it's in the English Department.

Miller : In English. They do courses in East Asian, they do Chicano/Chicaya, etc. So the goal is to get a range of literatures. The history comes - it's interesting - they have this feeling, maybe we ought to know something about history, so they use the Hazard Adams anthology. They read that the first year, but it's not taught. And this was a thing that the committee noticed. Nobody there is willing to teach the history of the development of literary theory, to show how Fred Jameson is a point in a very complicated historical development.

I hope you, Murray, can answer my question of why we want cross-cultural translation, a simple question.

Krieger : Well, you offered two possible reasons, really three. You mentioned the one of your speaker who said "respect," which suggests that, not that you're going to be essentially touched or transformed by it, but that it's out there and you doff your hat to it.

Miller : No, it's not quite that. He wanted more than that. He meant... I found it interesting that he used that word, and used it several times. He meant understanding enough about it so that you can respect its specificity. I think that's what he meant. But he recognized that even 
that little experience of getting inside, a little bit, African-American literature is going to be (his word) destabilizing. It's going to be profoundly troubling to somebody who comes from a different...

Iser : Because respect also implies that you don't understand all of it.

Miller : That's right. That's why he didn't say...

Readings : I think he's a reader of Kant. I mean, I think Anthony Appiah...

Miller : Well, the word Achtung...

Krieger : But there were two reasons: You mentioned that it's out there, it's something to be known like any other unknown object that could be the object of scholarship, even if it's Sanskrit cookbooks. And then you mentioned its possible values, symbolic, whatever. The Brothers Karamazov example: it somehow did something, gave you an access to something that...

Miller : You could get in no other way.

Krieger : That's right.

Miller : Even in translation something comes through to me which is absolutely irreplaceable.

Krieger : What's interesting is that you didn't mention at all what is usually put forward as the most obvious justification, the anthropological dimension, which gives you access to how a society is conceiving itself, how a fine mind can work at a given moment in history in a given place in the world with a given set of cultural institutions, and so on, and so on, within a language that is created by this culture, to which you have had no access.

Miller : Sure, that's not all that different from what I found puzzling and anxiety-making, let's say.

Anthropologists worry about that. My daughter Sally went to Nepal to study marriage customs there. She was taught as a structural anthropologist. Within that paradigm what you do is to reduce - she didn't at all do this - to reduce these laws to Western comprehensibility. You worry about kinship rules, and so on, then you write a treatise, which... I don't see that that's entirely different from translating Chinese poetry. It's a form of appropriation. 
Krieger : No, I think it is. Because, I think, from what little access I've had to bad translations, as you say, to cultures which are unknown to me. I'm thinking largely now of Indian cultures, since I spent a good deal of time there (it isn't that I learned marriage customs - I didn't mean anthropology in that sense - I mean anthropology in the old, philosophical anthropological notions of German nineteenth/twentieth century traditions), and I approached some rare notion of what it was like to be in this culture, to have these values and those values, whether about marriage, or war, or enemies, or friends, or lovers, or a family. I don't think any anthropological document or any series of data that I could receive from marriage offices or birth offices or any other sorts of records would give me this. Obviously, that's presumably why we read what (forgive me) we've been calling literature.

Miller : That's very arguable. I don't want to anticipate the discussion of Ernst's paper this afternoon, but he's right that the early Romantics were profoundly out of connection to the public, who violently rejected their work. Reading Schlegel would not be a way to learn about German culture at that time. Quite the reverse; it would be a way of learning about something very special and marginal to the normal assumptions of that culture. I noticed this in your paper, and it was the thing that I was anxious about.

Krieger : Obviously we have a couple of definitions of culture going here. You, in your paper, mentioned clearly the Arnoldian notion, and what has come to be the notion that most of our colleagues are more concerned about today, which is a very different one, a much more general notion of a popular, quotidian culture. Whereas what I meant was - and I think what you meant when you were reading The Brothers Karamozov - that you're not learning about what Russian culture is, not in any broad sense. But you are learning what it is for a fine, deeply self-conscious sensibility to be living at a given moment, in a given place, within a set of cultural givens. Now this may not tell me anything about the broad external range of living at a given moment as an ordinary citizen. If you will, it's the elitist thing that never lets go for any of us, really, at some point in the texts we read.

Miller : I think to be sure about that, I'd want to start learning a lot more about Russian culture than I know. What I thought in my innocence when I was a sophomore in college and first read Notes from the Underground - 
which had a powerful influence on me - I said, "There I am! Somebody at last who's like me!" When he says, "I'm a sick man, I'm a spiteful man, I think my liver is diseased." I thought that was funny. But I thought I was getting in touch with Fyodor Dostoyevsky, not with Russian culture.

Behler : Just a short intervention concerning reasons why to translate in general, and also cross-culturally: one aspect is perhaps the practice of translation. We should think of translation as a special gift of human beings, such as playing the piano, having a good voice, or being a good actor. These are special talents. We are talking mostly, when we speak about translation, from the heoretical point of view. We over-emphasize the difficulties and the cultural problems by questioning whether we can do it or not. But there's also a practice of translation which cuts through these questions. And it's fun, from this point of view; people do it out of a liking; they have something to communicate. I like to talk to real translators and ask them how they do it, and I also like to translate myself occasionally.

Miller : You're saying that your big Nietzsche translation is not just to contribute to knowledge in the English language, but out of a kind of love of the act itself of translation.

Behler : No, there I'm not really active, this is done by others. I was not thinking of that so much. I was thinking of...

Miller : You were talking of David Krell and the translation of Heidegger.

Behler : Translators translate certain authors only and not others, because there is this bond. That's also a reason why some translations originate and others not.

Miller : That's true. That is, as a kind of end in itself.

Readings : I want to ask a very short question here, which is: do we have a choice about translating? I mean, does anyone here try to argue that translation is something we either do or do not do? It seems to me clearly that we don't have a choice about it.

Derrida : I will continue along the same line. Of course, there is a very unlimited concept of translation. That is, translation is anything. Each time you speak you are already translating. If you refer to the canonical work by Jakobson of translation, he distinguishes between three types of translation, interlinguistic, and intradiscursive, 
intralinguistic. With these three concepts, you have everything. As soon as you open your mouth, you are translating. And as soon as you read, you are translating. Then, the question is not simply why to translate, because we are constantly translating. The question might be, why know? Let us assume that there is such a thing as literature in non-European so-called cultures. Let us assume this. Then does it follow from that that in these cultures they want to know their so-called literature, to teach it, to have a theory about it? That is, the process of knowing the literary, to know it objectively, to build a theory on it, and then to teach this theory, to have institutions in order to do that. These are a number of unavoidable problems, but the problem of the institution is absolutely... is intrinsically linked to what we are doing. Now to respect, to respect the other's culture or literature. If it means, as you said a moment ago, also to understand it, to know it, to know it from the inside. How are we to understand this act of knowledge? Is it separate from the idea of science? the idea of philosophy? the tradition of philosophy? Is it possible to have a theory of literature, a project of a theory of literature, without the history of Greek philosophy, Greek science, and so on and so forth? And you can't ask such questions without Eurocentrism. It's exactly the opposite, exactly the opposite. Well, it might be the opposite. Now when you mention, Hillis, the example of the cooking handbook. What is the cooking handbook? Whether it's difficult or impossible or not to appropriate a foreign culture, the first question would be, is it possible for us to appropriate ours? What does that mean, "to appropriate"? So politically I wouldn't like to have a choice between appropriating the foreign culture or appropriating mine. I mean, it's just as difficult, it's impossible. It's impossible to appropriate French. For me, French literature is something inappropriable. It's not the same kind of difficulty which is the Chinese culture, of course, because I'm supposed to know French, but in the end, in the end, appropriation is impossible. And I think that I agree with Hillis when he says it's an endless task, and perhaps not a task of appropriation; respect doesn't command appropriation. Now I close this parentheses and come back to the cooking handbook. We have in our tradition a number of literary works in which we have recipes. And the other way around: the cooking handbooks, of course, you cannot dissociate them from the history of the sacrifice, from religious content, and so on and so forth. And the same is true with literature. To understand Russian literature if you don't understand something which is not simply literary... And I'm not speaking in terms of social structure, but of religious structure, sacrifice. There is a 
first difficulty, that is to isolate literature from anything else, especially sacred texts or religious...

Miller : Such as this cooking handbook...

Derrida : And then the cooking handbook is probably full of religious contents.

Miller : That's why I chose that as an example.

Derrida : Now you can always transform and translate a given non-literary text, given that in everyday life it's non-literary, you can translate it into a literary text. The same with painting: you can transform... you take something, you frame it, you put it on the wall, and it's as a work of art. And the same sentence, as we all know, the same sentence of the same page of the same set of pages, can be, under certain conditions, translated into, transformed into a literary piece with a literary function. So to identify this literary function is a very very complicated gesture, and always unstable. There is only stabilization, which means non-natural stability, only stabilization when a number of people in a certain context agree to consider that this set of sentences are literary. But this is not part of the essence of the sentence, the intrinsic property of the sentence. It's a matter of convention, of relatively stabilized convention among a certain number of people.

Birus : This gives me the occasion to end up my argument that was interrupted by this discussion on translation. I completely agree with you that Goethe's concept of world literature has a strong Eurocentric component. But there is another interesting point: on the one hand, he resisted against merging rhetoric and poetry. But on the other hand, his concept of "world literature" included secondary literature too. And his starting point was not the literature, but people who make it: literatores. And he said that most important for the emerging world literature were the debates between writers. And in this case, I think your question about translating and knowing - Goethe's notion of world literature included this equally as the use of the word literature in English or "littérature" en francais, in the eighteenth century.

Derrida : But we know the concept of the university would be part of this space.

Birus : Yes, but only part of it. Science is only part of this. And this concept of literature, that doesn't only mean belles lettres, but what is written and more important what can be written. Well, there is always the 
danger of reification, but it is at the same time a very fluid concept.

Miller : Can I just enter in for a second to say that that agrees very closely with the meaning of the word "literature" in eighteenth-century England, which would include somebody's published letters, for example - that would be literature - or a diary, an autobiography. That is, what's happened, at least in the English speaking countries, is that by the, let's say, late nineteenth century, when you began to have departments of national literatures, the term "literature" got narrower and narrower. It's only fairly recently that it meant - as Jacques was saying, it's not very old anyway, the term "literature" - but the notion of literature as in our basic literature courses in which you have one section on lyric poetry, one on drama, and one on the novel, that's very recent...

Birus : But since Roman Jakobson, his early writings and his concept of literaturnost', we have quite an opposite concept of literature that is at the core of all poetry, literary function, literaturnost', and such things. It has changed into the opposite meaning.

Miller : It hasn't filtered down to beginning courses in English departments yet, in which what we still mean by "literature," is poetry, novels, drama. Literature would mean what's in the Norton Anthology.

Krieger : Although the practice in most universities now is far more latitudinarian than that.

Miller : Partly in reaction to that narrowness.

Krieger : True, of course, of course.

Iser : First of all I should like to stress that the notion of untranslatability that is floating around in our discussion is not something which is out there. It's not to be taken for the other, because whenever translation takes place, we produce a residual untranslatability. Therefore it cannot be identified as one essence. If we agree that a residual untranslatability is always produced in translation one might agree with Murray's idea of privileging poetry as a mode of translatability. Poetry is a form of translation that inscribes into itself a potential untranslatability whenever something is being transposed into a different register. Something similar happens when different cultures or cultural levels are translated into one another. There is always something which defies translation, and poetry is a model for such a 
residual untranslatability. In poetry untranslatability becomes an integral part of its structure, highlighting what resists transposition. In this respect poetry reveals something which remains largely hidden in a great many other acts of translation, such as getting to know what knowing is. There would not be such a zest for grasping what knowing is if there were a given frame of reference, or a transcendental stance for predication. We shall never be able to decide what knowing is when, for the sake of comprehension, we have to translate it into something other. Thus we get another type of translation, in the execution of which we have to monitor what we are doing when we translate. And that might turn out to be an unending process.

Krieger : Who is the self that monitors? How do you separate out a monitoring self from a translating self?

Iser : The very fact that we talk about getting to know what translation entails is already an attempt at monitoring one's own ideas regarding such an undertaking. By paying respect to what others do, we divide our own selves and scrutinize what we do.

Birus : But Wolfgang, is it not exactly the same what the Romantics called "reflection," and "reflection of reflection"?

Iser : No, not actually. The kind of self-monitoring which we seem to be engaged in implies suspension of our own presuppositions and a reflection on what is different from what we might be inclined to do. This is the reason why reflection has a double orientation focusing on the self and the other and simultaneously refraining from integrating these countervailing activities.

Birus : And then begins irony, Romantic irony, because it's not possible to finish up. this reflection.

Iser : Romantic irony indicates the impossibility of such an integration, whereas self-monitoring suspends the latter for the sake of scrutinizing what is in play.

Pfeiffer : But still Murray's question's there. I mean, not what is the self who does the monitoring, but what are the directions into which the monitoring is supposed to go. Is it, for instance, that we are supposed to intercept or to block or to interrupt certain habitual connotational loads from which we are suffering with the concept of literature?

Iser : Monitoring is watching. 
Pfeiffer : Monitoring is watching. For instance, would it be, just to go back to one of the, let's say, initial central well, shall I say concepts or metaphors of Murray should we allow him to keep the notion of having access to a culture, or should we rather monitor that expression in a way which would go maybe more into Jacques Derrida's notion that we cannot even have an access in any strong sense into our so-called own culture?

Wang : I should respond to some of these questions. I was listening, and I heard some comments about whether it's necessary to translate or to go to another culture, or why don't we just defend ours and worry about our own - something like that. After heard all about this, I feel it's really necessary then to go to another culture and to translate. I myself practice translation occasionally. Not too much, but whenever I translate, I translate from another culture, from Western culture. It's impossible for me to translate from Eastern culture. I don't do that at all. And I don't enjoy doing translation, but I still do it. And this is not only because I think it is my responsibility to introduce English literature to the Chinese readership, but also because I take it as some kind of practice for me to get myself close to a different aesthetic, a system that is so different from what I am used to. I need that irritation in order to keep myself creative. But I know it's very hard. I've been preparing a paper on translation for a conference in Taiwan in July. And I've cited poems from Old English, Chaucer, Shakespeare, and so on, to show to my colleagues there that there are all kinds of problems there. Sometimes I can even tell them that there's nothing poetic, for example, here from this huge passage of Milton.

Miller : Are you talking about Paradise Lost?

Wang : Yes. And sometimes it's impossible to translate Milton into Chinese poetry. It is probably all right to translate him, or Shakespeare, in prose. Then we translate just the cultural side, not the musical, poetic side.

Krieger : Ching-hsien, one thing. What you've said makes it clear, or suggests to me at least, that in the Chinese literary or poetic tradition, poetry is a far more separate kind of language from prose than it is in Milton, let's say.

Wang : Um hmm. 
Krieger : I have one other question. You can comment on that, but I want you to comment on one other thing. You say you only translate from the West to the East; you don't go the other way. But your own poetry, I know, is the subject of considerable translation, and I'm just wondering... You're the only person here who actually writes poems that have been translated from Chinese into the West. So it goes the other way from the way in which you translate. Would you translate them differently? How do you feel about the before and the after?

Wang : I just feel those poems are very strange to me. They are detached from me after they are put into English.

Derrida : They sound like Milton or something.

Wang : They sound like Milton. It's very far, very far... It's not really the kind of poetry I want to write. And I can't write in English. That's very strange. I can never do creative writing in English. I can write a paper or something like that, but not poetry.

Krieger : You've never written an English poem.

Wang : No, I've never done any English poetry.

Krieger : He doesn't want to write like Milton.

Birus : But for example, there were two or three years in Goethe's life he preferred to read his own Faust in French translation.

Yu : Why?

Birus : Well, it was not so close to him. He found a productive distance. He had the problem with finishing it up, and the printed German text was all too definitive. And so he looked for translations where it was fluid and open.

Krieger : But at the same time, of course, nineteenth century Germans all thought that Shakespeare, if he woke up, would read the German translation and think that he'd rather read himself in German. The whole question of the translation of Shakespeare into German in the nineteenth century is a very rich mine for us to discover what can be wrong with translation or what the problematic of translation is. 
Readings : I think it's not coincidental, though, that one comes back to certain names like that of Shakespeare in talking about translation, because it seems to me that at least in the English academy, we invented the notion of literature through an analogous appeal to Shakespeare, to the appeal that the Germans made to the Greeks. That is to say, he is our justice. In Ancient Greece, everything was white; in Shakespeare, everything was happy. There was a kind of organic community and unity, and there's a strong parallel to be drawn there. I mean, I would agree with everything you say about the strangeness of translation, but in some sense I would argue that one can't suggest that there is actually a literature. The notion of literature as something that is produced cannot be abstracted from the notion of translation. That is to say, it's not something secondary. We, in Britain, invent literature out of the notion of translation.

Krieger : But, Bill, the special problem is, as we see from what Ching-hsien said, that the kind of translation that has brought this group together covers so vast a distance. The gap across which the translation will have to bear, the body of its victim is incredibly greater (as we think of Chinese or Japanese or whatever else in relation to the West) than it is in the kinds of translation from the Greek or Latin, that Renaissance Europe made itself into in order to accommodate them, or rather made them into in order to accommodate Western Europe. The accommodations are clearly less undo-able than what seems to me to be the frightening distance we are contending with here. Indeed, to play, for a moment, Jacques' card: Is the word "translation" in any way the same word when we're talking about Goethe reading his Faust in French? I'm only talking about Ching-hsien reading his poem in English. Or at some point, does quantity translate into quality, does degree translate into kind? Are these really two radically different activities, these two kinds of... the translation from German to French, or French to English, or German to English on the one hand and translations between Western and Eastern languages?

Miller : I'm not sure, Murray. I think that just as you don't recognize Milton as possible in Chinese poetry, so when I read Hölderlin in English, I say, can this be great poetry? The lines seem so flat and prosaic. The only way I think you can read Hölderlin is n German. It really becomes something very strange in English. It looks like Paradise Lost in Chinese. 
Wang : I think you really need poetry in the original. When I read Milton in English, that's the greatest poetry.

Behler : I understand what you say, but I still try to resist this thought because it privileges certain forms and certain poets as being untranslatable, and then you have the distinction of good and bad poetry. Bad poetry can be translated; good poetry cannot be. I understand this fully, but I try to resist this attitude.

Derrida : Why do you want to resist? I'm not going to try to resist. I think that the best poets are the most untranslatable, and I keep to this...

Krieger : You haven't given that much away by saying that. I mean, you didn't mean to. This is not a statement that runs counter to anything else that you said. Or is it?

Derrida : You see, the paradox is this. What is easy to translate, what poem is prosaic language, just avoids translation. There is no experience of translation when we don't experience the untranslatable. That's why literature, or poetry, to the extent that it's rooted... it's absolutely linked to the idiom, to the idiom, to the extent that the idiom is not translatable, that the translation translates the untranslatable. That's why literature is the experience of translation, is what calls for translation. To write a poem, an untranslatable poem, calls for translation. The poem cries for being translated precisely because it can't be. That's why we try and translate Hölderlin and Milton and Mallarmé, and we know that they are not translatable. But that's why the untranslatability is not a negative concept. It's not opposed to translatability. Untranslatability is the element of translation. Wherever you have translatability, there is no translation, if I may formalize the statement that way. You have the experience of translation each time you know that you have to translate what remains, what will remain untranslated, or untranslatable, once you have translated it. That's why the untranslatability is not, for me, an external limit. It's part, it's a limit which runs through translation. And the experience of translation is the ongoing experience of untranslatability. And even when you publish a translation, you know that something hasn't been translated. And to the other you offer to share this experience of knowing how untranslatable it is by going back to the original. I give you some help with my imperfect translation. I'll give you the chance to go back to the original and to experience how untranslatable, 
and to learn the author's language, to learn the language of the poet.

Behler : If we interpret the term "untranslatability" in these subtle terms, then we fully agree. But I refuse to make untranslatability a category for good and bad poetry. If you say good poetry is untranslatable and bad poetry is translatable...

Derrida : It's untranslatable, but not as a stone - as some language which cries for translation.

Iser : Untranslatability also powers the acts of translation itself, and thus has repercussions on the energizing impulse that drives translation.

Birus : Yes, and it changes. Some things are untranslatable at a given time, and then it becomes translatable and there emerges another, a second intranslatability. For instance, the translations of Homer by Voss and others - they created a German hexameter. But then other things became obscured by this, and so there emerged the need for a prose translation, or the Hölderlin translation of fragments by Pindar. They created another untranslatability. And so I think translatability and untranslatability create each other.

Iser : What remains untranslatable is always differently cast by the very act of translation.

Birus : And important poetry may be such poetry that comes into this process that is not possible to end up with, but minor poetry - well, at some time it is translated. And you can forget it.

Miller : And if Jacques is right about translation - I'm thinking of Jakobson's distinction about intra-linguistic translation - wouldn't one say that teaching, the teaching that we do, is always in translation in one way or another? What comparative literature is, is the teaching of the translatability/untranslatability, the active experience over and over and over again of the difficulty of getting from one language into another. Which doesn't even mean that it's bad to teach things in translation it's better than not to teach them at all, as long as you say... as long as you have somebody who can say, well, there's a little problem with the translation here; let me tell you what the French, or the German, or even the Chinese actually says. We can teach students who don't know the language an immense amount in a minute by talking just a little bit about those problematic points. 